\title{
A new species of Melo (Gastropoda: Volutidae) from northwestern Australia
}

\author{
Hugh Morrison and Fred E. Wells \\ Department of Aquatic Zoology, Western Australian Museum, Francis Street, \\ Perth, Western Australia 6000, Australia
}

\begin{abstract}
A new species of volutid gastropod, Melo (Melocorona) ashmorensis, is described from Ashmore Reef off northern Western Australia. The new species is compared with three known tropical species of Melo (Melocorona): $M$. aethiopica (Linnaeus, 1758), M. amphora (Lightfoot, 1786), and M. broderipii (Gray in Griffith and Pidgeon, 1834). Key features of Melo ashmorensis are its large size (up to $283 \mathrm{~mm}$ long), and the spire is raised above the spines and above the top of the outer lip of shell. There are 13-16 very low, uniform spines per whorl which cease at or near the aperture line before the adult whorl. Melo amphora differs in being larger with a depressed spire, with 16-20 straight or curved spines which do not extend to the body whorl, and gradually increase in size, with the final spine often being very long and the highest of all. The protoconch is white in $M$. ashmorensis, compared to yellowish in $M$. broderipii. Spines are more numerous on $M$. broderipii (about 50 per whorl) and reach the end of the whorl on all specimens. The key characteristic of $M$. aethiopica is the very swollen outer lip which is flared in adults. The spire of $M$. aethiopica is depressed, and there are 28-34 spines per whorl.
\end{abstract}

Key words: new species, Melo, Volutidae, northwestern Australia, Ashmore Reef, Cartier Island, Hibernia Reef

\section{INTRODUCTION}

The continental shelf off northwestern Australia is one of the widest in the world, with a maximum width of $350 \mathrm{~km}$. The shelf is a continuous structure that extends from North West Cape, Western Australia, across the top of the continent to the tip of Cape York, Queensland. Open ocean atolls are located near the outer edge of the shelf in northwestern Australia. There are no signs of volcanic stacks in the centre, so the reefs are not classic Darwinian atolls. Instead they originated in shallow water and have grown vertically to remain in the shallows as the surrounding area became deeper (Carrigy and Fairbridge 1954). The fauna of these open ocean atolls was almost totally unknown until a series of expeditions was mounted by the Western Australian Museum to Rowley Shoals (1982), Scott and Seringapatam Reefs (1984) and Ashmore Reef and Cartier Island (1986) (Berry 1986; 1993). A few years later, the Northern Territory Museum worked at Ashmore Reef, Hibernia Reef and Cartier Island (Russell and Vail 1988; Russell and Hanley 1993). Results obtained were spectacular, and included the first specimen of the largest species of giant clam, Tridacna gigas (Linnaeus, 1758) collected in Western Australia (Wells and Slack-Smith 1986). From the various animal phyla examined about $20-25 \%$ of species recorded were new to Western Australia. In addition there were genera and species which were new to Australia. Many of the new Australian records were species commonly recorded on oceanic atolls throughout the Indo-Pacific, but which had not been recorded on the Australian continental coastline. The fauna was more closely related to that of the Great Barrier Reef in eastern Queensland than it was to the adjacent continental coastline in northwestern Australia (Wells 1986).

Molluscs collected in the surveys were recorded by a series of papers (Wilson 1985; Wells 1986; 1993; Wells and Slack-Smith 1986; Wells and Bryce 2000; Wells and Allen 2005; Willan 2005). Altogether these papers recorded over 900 species of shallow water molluscs from the offshore atolls. Since then there have been several species described from the atolls.

One feature of the molluscs was that there have been very few species of Volutidae collected from the offshore atolls (Wells 1993). Volutes lack a planktonic distributional phase in their life cycle; instead crawling young emerge from benthic egg masses (Wilson 1994). This severely restricts the dispersal capability of volutes and tends to lead to allopatric speciation. It appears that the atolls being located so far offshore presents a considerable barrier to the distribution of volutes. The single 
species of Melo collected was listed by Wells (1993) and Wilson (1994) as Melo amphora (Lightfoot, 1786) and by Willan (1993) as M. broderipii (Gray in Griffith and Pidgeon, 1834) and more recently as $M$. aethiopica (Linnaeus, 1758) (Willan 2005). Closer inspection of WAM material has led us to conclude this is in fact a new species, which is described here. Recently four additional volutes have been reported from Ashmore Reef. Amoria spenceriana (Gatliff, 1908) was originally described without a type locality, but Ludbrook (1953) subsequently designated Port Denison, north Queensland. Amoria spenceriana was considered to be a synonym of $A$. maculata (Swainson, 1822) by Wilson (1994). However, A. spenceriana is now regarded as being a valid species which is endemic to Ashmore Reef (Willan 1995; Bail and Poppe 2001). Two additional species of Amoria have been recorded by Willan (2005): $A$. cf. grayi (Ludbrook, 1953) and A. cf. damonii (Ludbrook, 1953). A new species, Cymbiola baili Prati-Muzetti and Raybaudi-Massilia, 1996, has also been described from Ashmore Reef. Thus the three of the five volutes now known from Ashmore Reef have been new taxa. It is likely that further collecting on these atolls will discover more undescribed species of molluscs.
All specimens examined during this study are lodged in the collections of the Western Australian Museum, Perth (WAM), the Hugh Morrison Collection (HMC), and the Merv Cooper Collection (MCC).

\section{TAXONOMY}

Family Volutidae Rafinesque, 1815

Genus Melo Broderip in Sowerby, 1826

Subgenus Melo (Melocorona) Pilsbry and Olsson, 1964

\section{Melo (Melocorona) ashmorensis sp. nov.}

Figures 1-4

\section{Material Examined}

Holotype, Ashmore Reef ( $\left.12^{\circ} 10^{\prime} S, 122^{\circ} 58^{\prime} E\right)$, collected in sand at $3 \mathrm{~m}$ depth, 1984, H. Morrison (WAM S.14955).

Paratypes: 1 specimen, Hibernia Reef (11 ${ }^{\circ} 55^{\prime} \mathrm{S}$, $\left.123^{\circ} 28^{\prime} \mathrm{E}\right)$, collected in sand on coral, $2 \mathrm{~m}$ depth, 19 September 1994, H. Morrison (WAM S.14956); 1

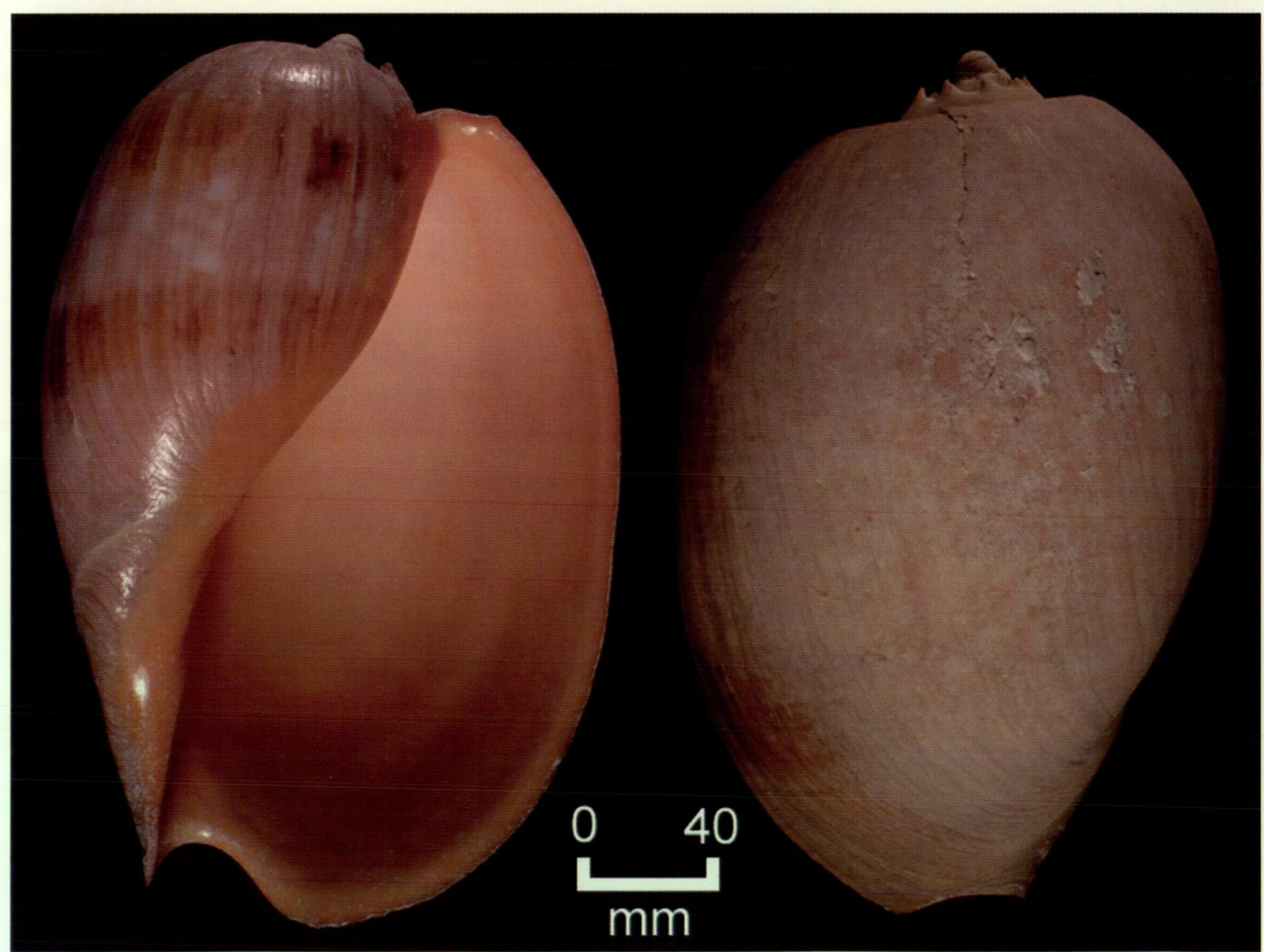

Figure 1 Apertural and dorsal views of holotype of Melo ashmorensis (WAM S. 14955). 


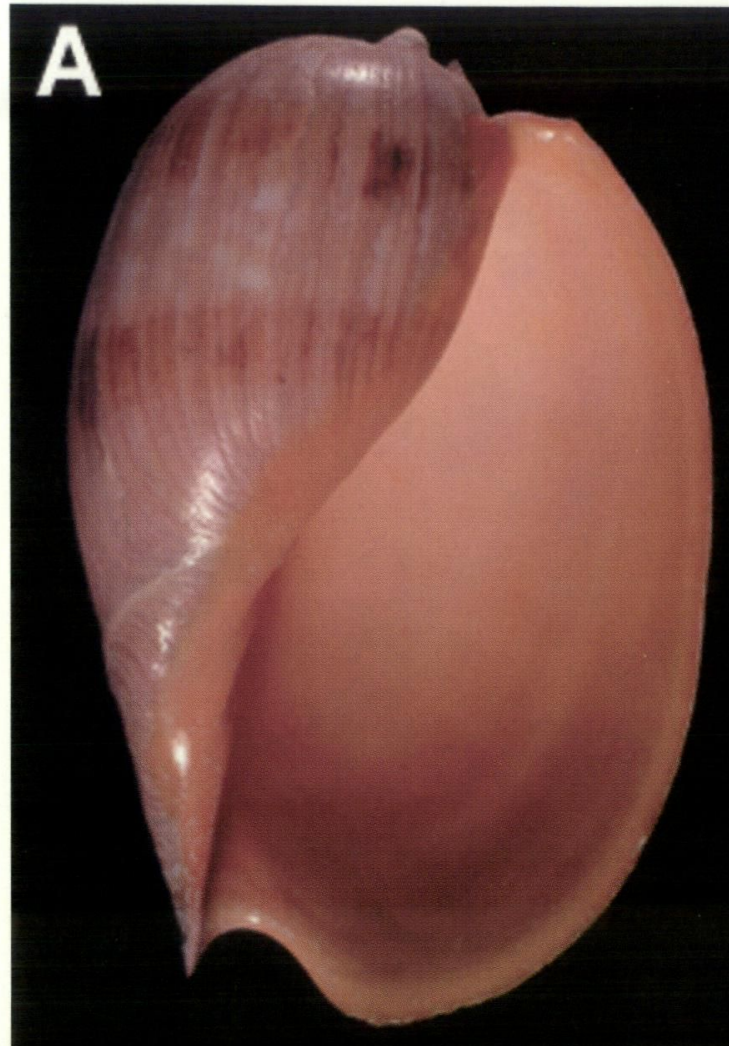

\section{B}

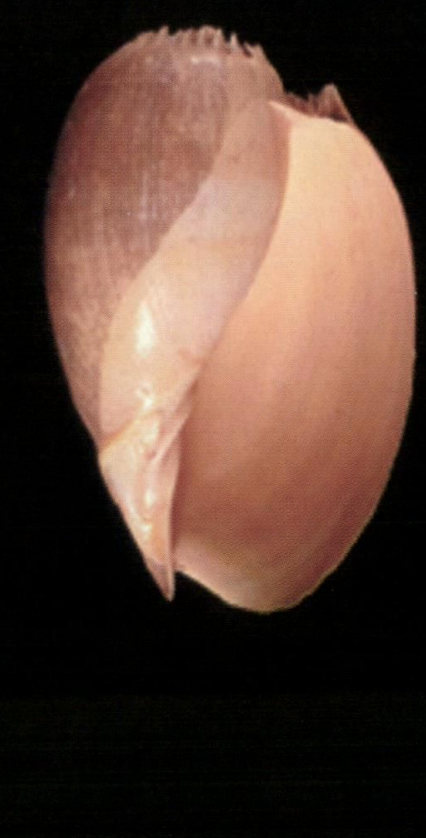

C

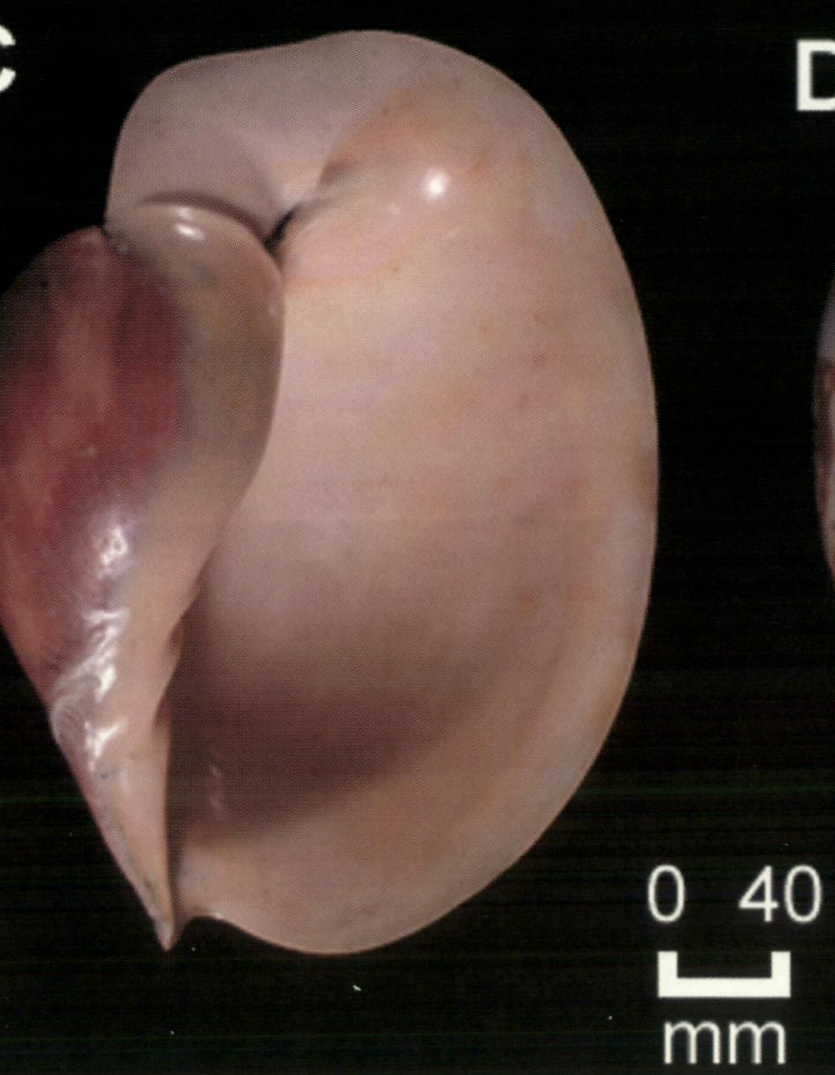

Figure 2 Comparison of apertural views of: A. Holotype of Melo ashmorensis (WAM S. 14955); B. M. broderipii (WAM S. 14959) (Balabac Island, Palawan, Philippines; $7^{\circ} 59^{\prime} \mathrm{N}, 117^{\circ} 06^{\prime} \mathrm{E}$ ); C. M. aethiopica (MCC; locality

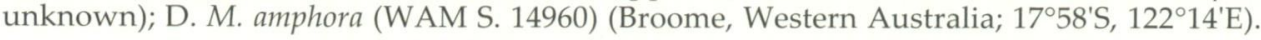




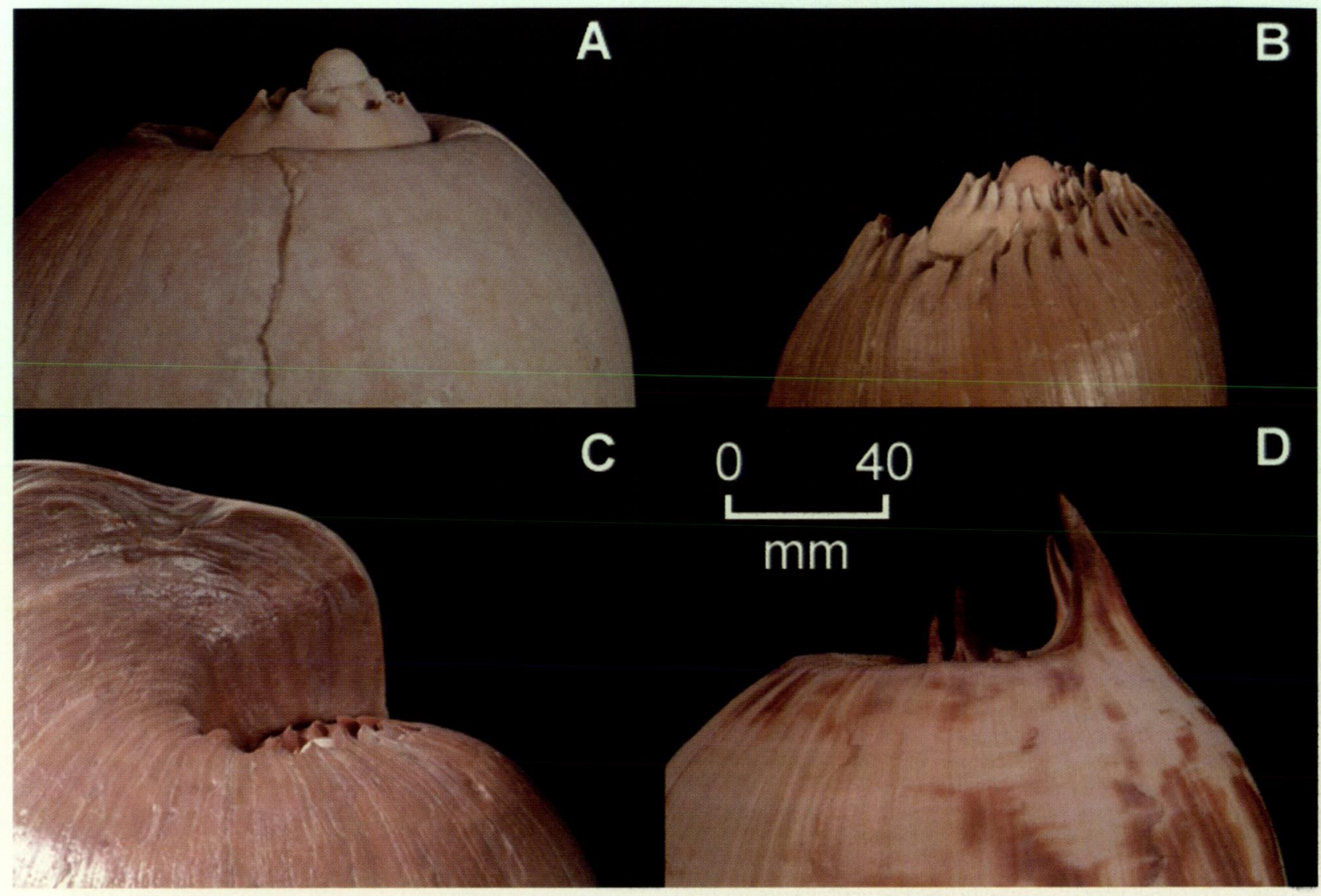

Figure 3 Comparison of apertural view of spines of: A. Holotype of Melo ashmorensis (WAM S. 14955); B. M. broderipii (WAM S. 14959); C. M. aethiopica (MCC); D. M. amphora (WAM S. 14960).

specimen, Hibernia Reef $\left(11^{\circ} 55^{\prime} \mathrm{S}, 123^{\circ} 28^{\prime} \mathrm{E}\right)$, collected in sand on coral, $2 \mathrm{~m}$ depth, 19 September 1994, H. Morrison (WAM S.14957); 1 specimen, Hibernia Reef $\left(11^{\circ} 55^{\prime} \mathrm{S}, 123^{\circ} 28^{\prime} \mathrm{E}\right)$, collected in sand on coral, 2 m depth, 19 September 1994, H. Morrison (HMC); 1 specimen, Ashmore Reef $\left(12^{\circ} 10^{\prime} \mathrm{S}, 122^{\circ} 58^{\prime} \mathrm{E}\right)$, Station 16 , transect from west of north lagoon to reef front, 17 September 1984, F.E. Wells and C.W. Bryce (WAM S.14958).

\section{Type locality}

Ashmore Reef $\left(12^{\circ} 17^{\prime} \mathrm{S}, 123^{\circ} 02^{\prime} \mathrm{E}\right)$ off northern Western Australia (Figure 5).

\section{Etymology}

Named after Ashmore Reef, northwestern Australia, where the species was first found.

\section{Diagnosis}

Large Melo, up to $283 \mathrm{~mm}$ long. Ovate, outer lip not extended dorsally. Protoconch white, 3 whorls. Teleoconch whorls with 13-16 low spines, 4-8 mm high, widely spaced, terminate at or near aperture line Spire extends above spines on body whorl and above top of outer lip of shell. 3 columellar plaits. Body whorl background colour mottled beige to brown. Two wide distinct dark brown bands divide shell into three roughly equal sections. Aperture bright orange

\section{Description}

Shell

Typical Melo shape, large, ovate, outer lip not extended dorsally. Up to $283 \mathrm{~mm}$ long and $179 \mathrm{~mm}$ wide (Table 1). Protoconch white, of three whorls, 7

Table 1 Details of the type material of Melo ashmorensis.

\begin{tabular}{lllcccc}
\hline Specimen & Repository & Locality & $\begin{array}{c}\text { Length } \\
(\mathbf{m m})\end{array}$ & $\begin{array}{c}\text { Width } \\
(\mathbf{m m})\end{array}$ & $\begin{array}{c}\text { Length/ } \\
\text { Width }\end{array}$ & $\begin{array}{c}\text { Shoulder } \\
\text { spines }\end{array}$ \\
\hline Holotype & WAM S.14955 & Ashmore Reef & 276 & 174 & 1.59 & 16 \\
Paratype & WAM S.14956 & Hibernia Reef & 283 & 179 & 1.58 & 13 \\
Paratype & WAM S.14957 & Hibernia Reef & 223 & 132 & 1.69 & 16 \\
Paratype & HMC & Hibernia Reef & 184 & 112 & 1.64 & 14 \\
Paratype & WAM S 14958 & Ashmore Reef & 98 & 56 & 1.75 & 16 \\
\hline
\end{tabular}




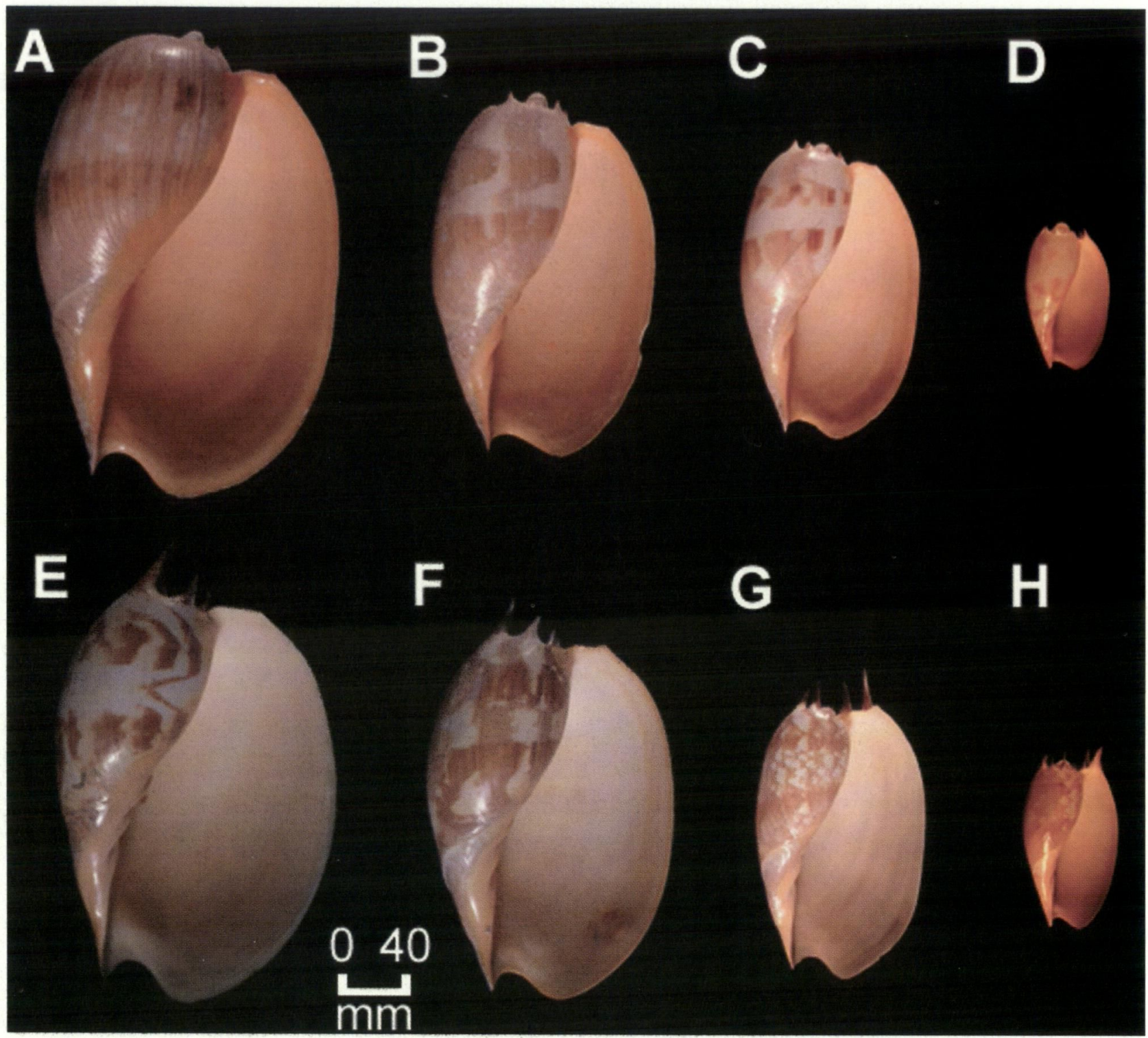

Figure 4 Comparison of growth series of Melo ashmorensis and M. amphora: A-D, M. ashmorensis: A. Holotype, WAM S. 14955. B. Paratype WAM S.14957. C. Paratype, HMC. D. Paratype WAM S. 14958. E-H. M. amphora. E. WAM S. 14960. F. WAM S. 14961. G. WAM S. 14961. H. WAM S. 14963.

$\mathrm{mm}$ high, $12 \mathrm{~mm}$ across. Three juvenile and adult whorls expand rapidly. Spire raised above spines on shoulder of upper whorls, and above top of outer lip of shell, 13-16 very low spines per whorl, widely spaced, of relatively uniform size (about 4-8 $\mathrm{mm})$, do not reach outer edge of whorl, instead cease at or near aperture line before adult whorl. Body whorl mottled beige to brown background with two wide distinct bands, which divide shell into three roughly equal sections. Bands on ventral surface are blocks of dark brown, become complete on body whorl. Aperture bright orange.

Animal

Not known.

\section{Distribution}

Known only from Ashmore Reef and Hibernia
Reef $\left(11^{\circ} 27^{\prime} \mathrm{S}, 123^{\circ} 30^{\prime} \mathrm{E}\right)$. Not known from nearby Cartier Island $\left(12^{\circ} 32^{\prime} \mathrm{S}, 123^{\circ} 33^{\prime} \mathrm{E}\right)$.

\section{Remarks}

The genus Melo has two subgenera: the monospecific Melo, with M. melo (Lightfoot, 1786) and Melocorona with all the remaining species, including M. ashmorensis. Poppe and Goto (1992) and Bail and Poppe (2001) recognise the following species in the subgenus: M. miltonis (Gray in Griffith and Pidgeon, 1834), M. amphora (Lightfoot, 1786), M. georgiana (Gray in Griffith and Pidgeon, 1834), M. umbilicatus (Broderip in Sowerby, 1826), M. aethiopica (Linnaeus, 1758) and M. broderipii (Gray in Griffith and Pidgeon, 1834). Melo miltonis is a southern Australian species which is very similar to the tropical Australian species Melo amphora (Lightfoot, 1786). 
Table 2 Comparison of relevant species in the volute subgenus Melocorona. Shell lengths after Poppe and Goto (1992).

\begin{tabular}{|c|c|c|c|c|c|c|c|}
\hline Species & $\begin{array}{l}\text { Range (after Poppe } \\
\text { and Goto, 1992) }\end{array}$ & $\begin{array}{l}\text { Shell } \\
\text { length } \\
(\mathrm{mm})\end{array}$ & $\begin{array}{l}\text { Columellar } \\
\text { plaits }\end{array}$ & Spire & $\begin{array}{l}\text { Outer } \\
\text { aperture }\end{array}$ & $\begin{array}{l}\text { Shoulder } \\
\text { spines }\end{array}$ & Colour \\
\hline M. ashmorensis & $\begin{array}{l}\text { Ashmore Reef and } \\
\text { Hibernia Reef, } \\
\text { northwestern Australia }\end{array}$ & 270 & 3 & $\begin{array}{l}\text { Spire raised above } \\
\text { spines and above top } \\
\text { of outer lip of shell. } \\
\text { Protoconch largely } \\
\text { eroded, white, } 3 \text { whorls }\end{array}$ & $\begin{array}{l}\text { Ovate, outer } \\
\text { lip not swollen. }\end{array}$ & $\begin{array}{l}\text { 13-16 very low } \\
\text { spines, widely spaced, } \\
\text { uniform size; do not } \\
\text { reach outer edge of } \\
\text { whorl, cease at or } \\
\text { near aperture line } \\
\text { before adult whorl }\end{array}$ & $\begin{array}{l}\text { Juvenile and adult shell } \\
\text { expands rapidly, } 3 \text { whorls. } \\
\text { Body whorl mottled beige to } \\
\text { brown background with } 2 \\
\text { wide distinct bands, which } \\
\text { divide shell into three } \\
\text { roughly equal sections. } \\
\text { Bands on ventral surface are } \\
\text { locks of dark brown, become } \\
\text { omplete on body whorl. } \\
\text { Aperture bright orange }\end{array}$ \\
\hline M. aethiopica & $\begin{array}{l}\text { Java, Indonesia to } \\
\text { Papua New Guinea }\end{array}$ & $\begin{array}{l}200-250 \\
\text { maximum } \\
\quad 348\end{array}$ & $3-4$ & $\begin{array}{l}\text { Spire very depressed. } \\
\text { Larhge white protoconch } \\
\text { white, } 31 / 2 \text { whorls }\end{array}$ & $\begin{array}{l}\text { Ovate, very } \\
\text { swollen outer } \\
\text { lip, flared in adults }\end{array}$ & $\begin{array}{l}\text { Up to } 28-34 \text { spines per } \\
\text { whorl. Very low, equal } \\
\text { height, generally face } \\
\text { in towards spire }\end{array}$ & $\begin{array}{l}\text { Juvenile and adult shell } \\
\text { expands rapidly, } 3 \text { whorls. } \\
\text { Dull dark brown on body } \\
\text { whorl, little or no banding } \\
\text { Aperture pale cream to } \\
\text { orange }\end{array}$ \\
\hline M. broderipii & $\begin{array}{l}\text { Primarily Philippines, } \\
\text { also Papua New Guinea }\end{array}$ & $\begin{array}{l}250-350 \\
\text { maximum } \\
\quad 371\end{array}$ & 4 & $\begin{array}{l}\text { Low but raised. Large } \\
\text { yellow protoconch, } 4 \\
\text { whorls }\end{array}$ & $\begin{array}{l}\text { Ovate spines } \\
\text { numerous, low }\end{array}$ & $\begin{array}{l}\text { About } 50 \text { spines per } \\
\text { whorl, equidistant, low } \\
\text { equal height, erect, reach } \\
\text { end of whorl on all } \\
\text { specimens examined }\end{array}$ & $\begin{array}{l}\text { Juvenile and adult shell } \\
\text { expands rapidly, } 3 \text { whorls. } \\
\text { Body whorl pale yellow to } \\
\text { straw colour, } 2 \text { indistinct } \\
\text { bands, generally central to } \\
\text { body whorl. Aperture } \\
\text { uniform pale yellow }\end{array}$ \\
\hline
\end{tabular}




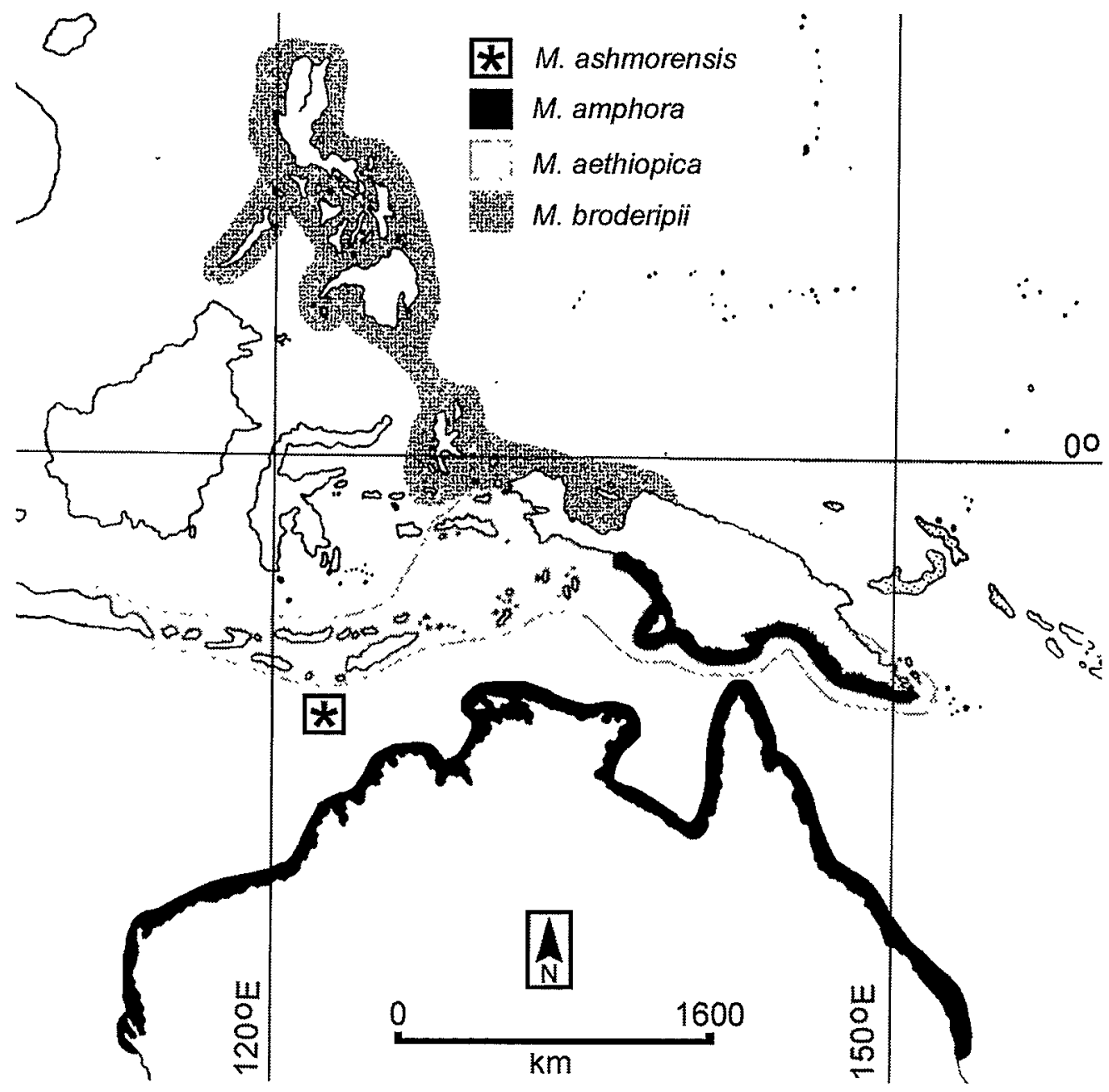

Figure 5 Map of northern Australia and the western Pacific Ocean showing the distribution of species of Melo (Melocorona) discussed in the text.

Apparent hybrids between the two species occur in the Shark Bay region of Western Australia (Wilson 1994). Similarly, Wilson (1994) considers $M$. georgiana to be a synonym of $M$. amphora. Weaver and duPont (1970) and Wilson (1994) regard the Queensland species $M$. umbilicatus as closest to $M$. aethiopica. None of these species ( $M$. miltonis, $M$. georgiana or $M$. umbilicatus) are discussed further.

As indicated on Table 2, M. ashmorensis is restricted to Ashmore Reef and Hibernia Reef, where no other species of Melo are known to occur.

Melo ashmorensis is closest to M. amphora, and both Wells (1986) and Wilson (1994) considered it to be $M$. amphora. While juveniles are in fact very close in appearance (Plate 4; Table 2), $M$. amphora grows twice as large as $M$. ashmorensis. Key differences are that the spire is raised above the shoulder spines in M. ashmorensis while it is depressed in M. amphora, and is well below the spines. There are 13-16, very low, widely spaced shoulder spines of uniform size which do not reach the outer edge of the body whorl in M. ashmorensis. In fact, the spines cease at, or near, the aperture line before the adult whorl. In contrast, the spines of $M$. amphora are straight or curved, usually erect, 16-20 per whorl, do not extend to the body whorl, and gradually increase in size, with the final spine often being very long and the highest of all. The colour of $M$. ashmorensis is relatively uniform. The body whorl background colour is mottled beige to brown, with two, wide, distinct bands which divide shell into three roughly equal sections. On the ventral surface the bands start as blocks of dark brown and become continuous on the body whorl. The aperture is bright orange. In contrast, the basal colour and pattern on the body whorl are variable in $M$. amphora. Juveniles often have wavy or zigzag banding. The body whorl of mature shells is generally uniform pale cream to brown. The aperture is uniformly pale yellow to straw colour.

Willan (1993) originally identified Ashmore specimens as $M$. broderipii. The protoconch is white in $M$. ashmorensis, compared to yellowish in $M$. broderipii. Shoulder spines are much more numerous on $M$. broderipii (about 50 per whorl compared to 13-16) and reach the end of the whorl 
on all specimens, instead of not occurring on the body whorl in $M$. ashmorensis. The body whorl of $M$. broderipii is pale yellow to straw in colour, with two indistinct bands, which are central to the body whorl and do not divide the whorl into thirds. The aperture is a uniform pale yellow, not orange.

Willan (2005) later tentatively identified $M$. ashmorensis as $M$. aethiopica. The key characteristic of $M$. aethiopica is the very swollen outer lip which is flared in adults. The spire of $M$. aethiopica is depressed instead of raised, and there are 28-34 spines per whorl which face in towards the spire, compared to only 13-16 spines per whorl on $M$. ashmorensis.

The shell is a dull dark brown on the body whorl of $M$. aethiopica with little or no banding and the aperture is pale cream to orange.

\section{DISCUSSION}

Melo ashmorensis is clearly not one of the presently recognised species of Melo (Melocorona). There is a possibility that the species has been given a name which is currently regarded as a synonym of another species. We believe this is very unlikely for a number of reasons. Many individuals in the population are small, and closely resemble $M$. amphora. Publications by Wells (1993) and Wilson (1994) incorrectly identified $M$. ashmorensis as $M$. amphora. The species is restricted to the very small area of Ashmore Reef and Hibernia Reef. The reefs were discovered in 1811, and were under British jurisdiction. They were not visited by the very early expeditions to Australia which resulted in nonexistent or vague type localities such as "New Holland". The most likely location for a Melo type from Ashmore is the Natural History Museum, London. The type of A. spenceriana is in the Museum Victoria. During the nineteenth century the Australian Museum, Sydney had the largest mollusc collection in Australia; there are no Melo types from Ashmore or Hibernia Reefs in the three museums. Nor are there types in the present collections which have extensive Sahul Shelf material, the Western Australian Museum and the Northern Territory Museum.

Willan (1993) originally identified Ashmore specimens as $M$. broderipii. He later (Willan, 2005) has independently examined the taxonomic status of Melo from Ashmore and Hibernia Reefs, and tentatively identified the material as $M$. aethiopica. He concluded that "either these populations represent a new species ... or the separation between $M$. aethiopica and $M$. broderipii is artificial and the two are conspecific. I do not have enough material of Melo specimens from Asia to decide between these two alternatives, and so for the time being I have used the name $M$. cf. aethiopica." Examination of Figures 2 and 3 and Table 2 demon- strate that $M$. aethiopica and $M$. broderipii are in fact separate species and are distinct from $M$. ashmorensis.

\section{ACKNOWLEDGEMENTS}

We are pleased to thank Glad Hansen (WAM), Allan Limpus, Peter Clarkson and Mike Claydon and Dr Henry Chaney of the Santa Barbara Museum of Natural History for discussions and reviewing specimens, Clay Bryce for taking the photographs, Corey Whisson for technical assistance, and Merv Cooper the loan of a specimen. Information on Melo types came from Drs John Taylor, Mark Norman and the website of the Australian Museum, and personal knowledge of the collections of the Western Australian Museum and Northern Territory Museum. We also thank Drs. John Taylor, Natural History Museum, London, and Richard Willan, Northern Territory Museum, for very helpful comments on the manuscript.

\section{REFERENCES}

Bail, P. and Poppe, G.T. (2001). A taxonomic introduction to the Volutidae. A Conchological Iconography. ConchBooks, Hackenheim, Germany.

Berry, P.F. (ed.). (1986). Faunal survey of the Rowley Shoals and Scott Reef, Western Australia. Records of the Western Australian Museum Supplement 25: 41-58.

Berry, P.F. (ed.). (1993). Marine faunal surveys of Ashmore Reef and Cartier Island, North-western Australia. Records of the Western Australian Museum Supplement 44.

Carrigy, M.A. and Fairbridge, R.W. (1954). Recent sedimentation, physiography and structure of the continental shelves of Western Australia. Journal of the Royal Society of Western Australia 38: 65-95.

Ludbrook, N.H. (1953). Systematic revision of the volutid genus Amoria. Proceedings of the Malacological Society of London 30: 131-153.

Poppe, G.T. and Goto, Y. (1992). Volutes. Mostra Mondiale Malacologia, Cupra Maritima, Italy.

Prati-Muzetti, M. and Raybaudi-Massilia, M. (1996). A new species of Cymbiola from Ashmore Reef Timor Sea. World Shells Magazine 18 (September 1996): 46-48.

Russell, B.C. and Hanley, J.R. (1993). The marine biological resources and heritage values of Cartier and Hibernia Reefs, Timor Sea. Unpublished report of the Northern Territory Museum of Arts and Sciences, Darwin, Northern Territory.

Russell, B.C. and Vail, L.L. (1988). Report on traditional Indonesian fishing activities at Ashmore Reef Nature Reserve. Northern Territory Museum, Darwin, unpublished report to the Australian National Parks and Wildlife Service, Canberra.

Weaver, C.S. and duPont, J.E. (1970). The Living Volutes. A monograph of the Recent Volutidae of the world. Delaware Museum of Natural History, Monograph Series No. 1: 1-375.

Wells, F.E. (1986). Zoogeographic affinities of 
prosobranch gastropods on offshore coral reefs in northwestern Australia. Veliger 29: 191-199.

Wells, F.E. (1993). Molluscs of Ashmore Reef and Cartier Island. In Berry, P.F. (ed.) Marine faunal surveys of Ashmore Reef and Cartier Island, North-western Australia. Records of the Western Australian Museum Supplement 44: 25-45.

Wells, F.E. and Allen, G.R. (2005). Marine biodiversity on offshore coral reefs in northwestern Australia. In Understanding the Cultural and Natural Heritage Values and Management Challenges of the Ashmore Region Proceedings of a Symposium Organised by the Australian Marine Sciences association and the Museum and Art Gallery of the Northern Territory, Darwin, 4-6 April 2001. Edited by B.C. Russell, H.K. Larson, C.J. Glasby, R.C. Willan, and J. Martin. The Beagle, Records of the Museums and Art Galleries of the Northern Territory 20: 43-50.

Wells, F.E. and Bryce, C.W. (2000). Molluscan surveys of offshore coral reefs in northwestern Australia and adjacent biogeographical areas. Phuket Marine Biological Center Special Publication 21: 395-404.

Wells, F.E. and Slack-Smith, S.M. (1986). Part IV. Molluscs. In Berry, P.F. (ed.) Faunal survey of the Rowley Shoals and Scott Reef, Western Australia. Records of the Western Australian Museum Supplement 25: 41-58.

Willan, R.C. (1993). Molluscs. In Russell, B.C. and Hanley, J.R. (eds.) The marine biological resources and heritage values of Cartier and Hibernia Reefs, Timor Sea.
Unpublished report of the Northern Territory Museum of Arts and Sciences, Darwin, Northern Territory.

Willan, R.C. 1995. Corrections to the type locality and zoogeographic range for three species of Australasian volutes (Volutidae: Amoriinae and Zidoninae). The Veliger 38: 152-157.

Willan, R. C. (2005). The molluscan fauns from the emergent reefs of the northernmost Sahul Shelf, Timor Sea - Ashmore, Cartier and Hibernia reefs: biodiversity and zoogeography. In Understanding the Cultural and Natural Heritage Values and Management Challenges of the Ashmore Region Proceedings of a Symposium Organised by the Australian Marine Sciences association and the Museum and Art Gallery of the Northern Territory, Darwin, 4-6 April 2001. Edited by B.C. Russell, H.K. Larson, C.J. Glasby, R.C. Willan, and J. Martin. The Beagle, Records of the Museums and Art Galleries of the Northern Territory 20: 43-50.

Wilson, B.R. (1985). Notes on a brief visit to Seringapatam Atoll, North West Shelf, Australia. Atoll Research Bulletin 292: 83-100.

Wilson, B.R. (1994). Australian Marine Shells. Odyssey Publishing, Kallaroo, Western Australia. Volume 2.

Manuscript received 10 August 2004; accepted 31 January 2005 